\title{
DAYA KEKUATAN TAWAR MENAWAR PENGUSAHA SLONDOK DI DESA SUMURARUM KECAMATAN GRABAG KABUPATEN MAGELANG
}

\author{
R. Manimabi,* S. H. Priyanto, H. J. Nadapdap \\ Fakultas Pertanian dan Bisnis, Program Studi Agribisnis, Universitas Kristen Satya Wacana \\ *email: Ruthmanimabi@gmail.com
}

Diterima 12 Maret 2018, disetujui 6 Mei 2018

\begin{abstract}
In improving and developing slondok business, it is necessary to analyze the factors that influence and the bargaining power factor owned by slondok entrepreneurs. This study aims to: (1) Know the bargaining power owned by slondok entrepreneurs in Sumurarum Village, Grabag Subdistrict (2) To analyze alternative strategies applied by slondok entrepreneurs in increasing the bargaining power of slondok. This research method is qualitative with descriptive design. Determination of participants in this study using purposive techniques. The results show that the quantity of purchase, purchase information, sales quantity, sales strategy, consumer information, purchase cost, product differentiation and brand identity, promotion, technology, product innovation in the form of variation of taste, large market share controlled by slondok entrepreneurs, the employee owned by slondok entrepreneur has the power in raising the bargaining power of slondok. Alternative strategies applied by slondok entrepreneurs are taste innovation, providing fast service, brand awareness, and maintaining good relationships.

Keywords: agroindustri, industri kecil, 2 kekuatan Porter, strategi generik
\end{abstract}

\section{PENDAHULUAN}

Pembangunan agroindustri merupakan kelanjutan dari pembangunan pertanian yang dapat memberikan nilai tambah melalui kegiatan hilir (off farm agribusiness), berupa agroindustri dan jasa berbasis pertanian. Sehingga perlu adanya strategi yang dapat diterapkan guna terciptanya industri-industri kecil dengan tujuan memanfaatkan sumber daya alam dan sumber daya manusia. Tingkat perkembangan sektor industri di Indonesia masih relatif rendah, namun disadari pengembangan industri kecil bukan saja penting bagi suatu jalur ke arah pemerataan hasil-hasil pembangunan, tetapi juga sebagai unsur pokok seluruh struktur industri di Indonesia yang dengan investasi kecil dapat berproduksi secara efektif serta dapat pula menyerap tenaga kerja. Industri kecil merupakan kegiatan ekonomi rakyat mempunyai kedudukan, potensi dan peran yang strategis untuk mewujudkan struktur perekonomian nasional yang makin berimbang berdasarkan demokrasi ekonomi. Dengan adanya peningkatan usaha pada sektor pertanian tentunya diharapkan dapat memberikan peluang usaha untuk industriindustri yang ada di Indonesia agar dapat terus berkembang memperluas usaha serta pangsa pasar yang ada. Oleh karena itu, dibutuhkan kajian industri untuk melihat peluang dan ancaman yang ada agar suatu pengusaha dapat terus berkembang.

Menurut Porter (2008), daya tawar pembeli pada industri berperan dalam menekan harga untuk turun, serta memberikan penawaran dalam peningkatan 
kualitas ataupun layanan yang lebih, dan membuat competitor saling bersaing satu sama lain.

Porter memiliki "Lima Kekuatan Persaingan" sebagai alat untuk menganalisis lingkungan persaingan industri. Lima kekuatan persaingan tersebut adalah ancaman pendatang baru, kekuatan tawar menawar pemasok, kekuatan tawar menawar pembeli, ancaman produk subtitusi, persaingan di dalam industri. Lima kekuatan tersebut secara bersama-sama menentukan intensitas persaingan dan kemampuan dalam sebuah industri. Dengan demikian analisis terhadap "Lima Kekuatan Persaingan" perlu dilakukan jika suatu industri ingin bersaing dalam pasar yang kompetitif. Model lima kekuatan persaingan memperluas wilayah analisi persaingan. Secara histori ketika mempelajari lingkungan persaingan, perusahaan berkonsentrasi pada perusahaan yang secara langsung bersaing dengan mereka. Akan tetapi pada masa sekarang dilihat sebagai sebuah pengelompokan berbagai cara alternatif bagi para pelanggan untuk mendapatkan nilai yang mereka inginkan, dan bukan sebagai perang diantara pesaingpesaing langsung. Menurut Hunger dan Wheelen (2010), strategi bersaing atau strategi bisnis berpusat pada peningkatan posisi bersaing produk dan jasa perusahaan dalam pasar tertentu yang dilayani perusahaan. Inti dari persaingan adalah proses dinamis dimana suatu keseimbangan tidak akan pernah dicapai dan suatu keadaan dimana struktur industri terus menerus diperbaharui.

Menurut Porter dalam Agus Maulana 2011 semakin besar sebuah perusahaan semakin besar pula aksesnya pada sumber daya, dan pada umumnya dapat memilih strategi bersaing dengan dasar keunggulan biaya diferensiasi, sedangkan perusahaan yang lebih kecil sering bersaing dengan dasar fokus. Porter menekankan perlunya ahli strategi perusahaan untuk melakukan analisis biaya manfaat untuk mengevaluasi "peluang bersama" di antara memperkuat keunggulan bersaing tergantung pada berbagai faktor seperti tipe industri, ukuran perusahaan, dan sifat persaingan. Beberapa strategi yang dapat dikembangkan adalah keunggulan biaya, diferensiasi atau fokus.

Kabupaten Magelang memiliki berbagai macam usaha agroindustri, yang memberikan sumbangan atau kontribusi bagi daerah baik dari segi penyerapan tenaga kerja, pertumbuhan ekonomi daerah dan bagi kesejahteraan pelakunya. Salah satu dari berbagai macam usaha agroindustri di Kabupaten Magelang adalah Industri Slondok. Sentra Industri Slondok mampu menciptakan lapangan kerja dan berkontribusi terhadap pendapatan masyarakat. Bahan dasar pembuatan slondok adalah ubi kayu. Pada penelitian ini, akan meneliti salah satu perusahaan perseorangan yang mendistribusikan dan menjual berbagai produk singkong salah satunya slondok. Perusahaan ini dimiliki oleh Ismono yang berlokasi di Dusun Porwogondo Desa Sumurarum Kecamatan Grabag, Kabupaten Magelang. Aktivitas usaha yang dilakukan adalah mendistribusikan hasil olahan singkong ke berbagai pasar dan kota baik di pulau Jawa maupun di luar Pulau Jawa, selain itu perusahaan juga melakukan penjualan langsung kepada konsumen.

\section{METODE PENELITIAN}

Penelitian dilaksanakan pada bulan April - Mei 2017 berlokasi di Dusun Porwogondo Desa Sumurarum Kecamatan Grabag. Pemilihan lokasi dilakukan secara sengaja (purposive) dengan pertimbangan Desa Sumurarum merupakan sentra pengolahan singkong (slondok).

Jenis penelitian ini menggunakan penelitian deskriptif kualitatif, yaitu penelitian yang datanya dinyatakan dalam bentuk verbal dan dianalisis tanpa menggunakan teknik statistik. Penelitian deskriptif adalah penelitian yang dilakukan untuk mengetahui nilai variabel mandiri, baik satu variabel atau lebih (independent) tanpa membuat perbandingan, atau menghubungkan dengan variabel lain. Dalam penelitian 
kualitatif lebih menekankan pada proses, maka penelitian kualitatif dalam melihat hubungan antar variabel pada obyek yang diteliti lebih bersifat interaktif yaitu saling mempengaruhi (reciprocal / interaktif), sehingga tidak diketahui mana variabel independen dan dependennya (Sangadji, Sopiah, 2010 dan Sugiyono, 2012)

Pada penelitian ini, peneliti menggunakan purposive sampling, dimana purposive sampling adalah informan dipilih dengan pertimbangan tertentu, misalnya orang tersebut dianggap paling tahu tentang apa yang kita harapkan atau mungkin ia sebagai pengusaha sehingga akan memudahkan peneliti menjelajahi objek atau situasi sosial yang diteliti.

Unit analisis dalam penelitian ini adalah pengusaha slondok di Desa Sumurarum Kecamatan Grabag. Sedangkan unit amatan yaitu seberapa besar kekuatan tawar menawar yang digunakan oleh pengusaha slondok, dan alternatif strategi yang diterapkan oleh pengusaha slondok.

Teknik yang digunakan dalam pengumpulan data adalah dengan wawancara dan dokumentasi: Wawancara, menurut Sugiyono (2012), digunakan sebagai teknik pengumpulan data karena peneliti ingin melakukan studi pendahuluan untuk menemukan permasalahan yang harus diteliti, dan untuk mengetahui hal-hal dari partisipan yang lebih mendalam. Teknik pengumpulan data ini lebih mendasar pada laporan tentang diri sendiri atau self-report, atau setidaknya berdasarkan pada pengetahuan dan/atau keyakinan pribadi.

Jenis dan sumber data yang diperlukan dalam penelitian ini adalah: Data Primer (Primary Data), Menurut Indriantoro dan Supomo (2011), data primer adalah data yang diperoleh secara langsung dari sumber asli (tidak melalui media perantara). Data primer dapat berupa opini subyek secara individual atau kelompok, hasil observasi terhadap suatu benda (fisik), kejadian atau kegiatan. Data primer yang diperoleh adalah berupa wawancara dengan pembeli selaku pengusaha slondok serta ketua kelompok tani. Data
Sekunder (Secondary Data), Data sekunder adalah data penelitian yang diperoleh peneliti dengan melalui media perantara (diperoleh dan dicatat oleh pihak lain) yang berupa bukti, catatan atau laporan historis yang telah tersusun dalam arsip (data dokumenter) yang dipublikasikan maupun yang tidak dipublikasikan (Indriantoro dan Supomo, 2011).

Dalam penelitian ini partisipan yang digunakan berjumlah 3 orang yaitu pengusaha slondok di Desa Sumurarum. Penentuan partisipan menggunakan teknik purposive. Purposive adalah teknik pengambilan sampel sumber data dengan pertimbangan tertentu yaitu sesuai kebutuhan dan tujuan dari penelitian.

Penelitian ini dilakukan dengan memilih partisipan yang dianggap mengetahui informasi dan masalah secara menyeluruh dan mendalam yang dapat dipercaya untuk menjadi sumber daya yang sesuai, Sutopo (2016). Adapun Key Informant yang dilibatkan dalam penelitian ini adalah ketua kelompok tani.

Uji keabsahan data pada penelitian ini dilakukan dengan menggunakan teknik triangulasi. Teknik triangulasi merupakan suatu teknik yang digunakan peneliti untuk mengumpulkan data sekaligus menguji kredibilitas dari data tersebut, yaitu dengan mengecek kredibilitas data dari berbagai sumber dengan berbagai teknik pengumpulan data, dan berbagai waktu (Sugiyono, 2011). Proses triangulasi dilakukan secara terusmenerus selama proses pengumpulan data, hingga pada waktu yang ditentukan atau di anggap peneliti telah cukup dan sudah tidak ada lagi perbedaan-perbedaan yang harus dikonfirmasikan kepada informan. Bungin (2011), triangulasi yang digunakan dalam menguji keabsahan data, salah satunya adalah dengan menggunakan metode triangulasi sumber data. Triangulasi sumber data dilakukan dengan membandingan dan mengecek keakuratan informasi yang di dapat dari berbagai informan dengan melalui waktu dan sumber yang berbeda.

Metode analisis data yang digunakan 
dalam penelitian ini adalah penelitian deskriptif kualitatif. Menurut Miles dan Huberrman (1994), teknik analisis data memiliki tiga komponen yaitu:

a. Reduksi Data, dimaksudkan bahwa dalam tahap ini sebagai proses pemilihan data dan informasi yang telah didapatkan selama melakukan penelitian dilapangan. Dalam tahap ini peneliti fokus pada peyederhanaan data yang diperoleh. Setelah data yang dipeoleh mampu diringkas, peneliti dapat menemukan konsep-konsep serta pola data yang diinginkan yang kemudian dirancang dalam bentuk hasil analisa akhir.

b. Penyajian Data, merupakan sebuah proses yang menyajikan data penelitian dalam sebuah kesatuan yaitu hasil akhir penelitian melalui kalimat yang disusun secara sistematis dan logis sehingga mudah dipahami. Oleh karena itulah, sangat diperlukan penyajian data yang jelas dan sistematis dalam membantu peneiti menyelesaikan pekerjaannya.

c. Kesimpulan, merupakan implikasi dari prinsip induktif. Selain itu, kesimpulan diverifikasi selama penelitian berlangsung guna memperoleh kebenaran tentang sebuah data dan informasi. Secara keseluruhan, data dan informasi yang diperoleh akan diuji kebenarannya, kekuatannya, serta kecocokkannya dengan tujuan sebagai media validitasnya.

\section{HASIL DAN PEMBAHASAN}

\section{Analisis Bargaining Power Pengusaha Slondok di Desa Sumurarum}

Alat kekuatan tawar menawar pada pengusaha slondok di Desa Sumurarum dilakukan dengan pengamatan langsung, wawancara dan menganalisis laporan produksi. Secara umum alat kekuatan tawar menawar pengusaha dipengaruhi oleh beberapa variabel yaitu kuantitaspembelian, informasi pembelian, kuantitas penjualan, strategi penjualan, informasi konsumen, biaya pembelian, deferensiasi produk dan identitas merek, promosi, tenaga kerja dan pangsa pasar.

Menurut Porter dalam Agus Mandala (2011), kuantitas pembelian bahan baku artinya jika pembelian dalam jumlah besar merupakan kekuatan yang ampuh terutama jika biaya tetap dari sebuah industri besar, sehingga perusahaan akan berusaha untuk menjaga agar kapasitasnya tetap terisi. Dalam melakukan pembelian bahan baku pengusaha membeli bahan baku dari beberapa pemasok dalam jumlah yang banyak yaitu 3 ton bahan baku untuk sekali produksi. Produksi slondok dilakukan tiap 10 hari sekali sehingga dalam sebulan pengusaha membutuhkan 9 ton bahan baku. Artinya pengusaha membeli bahan baku dalam jumlah besar sehingga hal ini merupakan kekuatan bagi pengusaha dalam melakukan tawar menawar. Berikut pernyataan pengusaha :

Dalam sekali pembelian itu butuh 3 ton karena kami produksi tiap 10 hari sekali. Dan saya punya pemasok bahan baku ada dari Boyolali, Temanggung, Gunung Kidul, dan Wonosobo. Kalau dari satu pemasok saja ya jelas tidak cukup. Untuk slondok saya pake semua jenis singkong tapi singkong yang bagus itu kulit tipis dan daging tebal. Kalau singkong langka saya pake singkong jenis pahit tapi harus dijemur dulu selama 3 hari biar nggak keracunan. (P3, 11-18)

Pengusaha menyadari bahwa pembelian dalam jumlah yang banyak merupakan kekuatan yang ampuh karena dengan demikian pengusaha mampu menentukan harga, menentukan kualitas serta menentukan kuantitas bahan baku. Pengusaha dalam melakukan tawar menawar dapat menekan harga bahan baku untuk turun terutama jika biaya tetap dari perusahaan besar, sehingga perusahaan akan berusaha menjaga agar kapasitasnya tetap terisi. Kuantitas pembelian yang dilakukan oleh pengusaha mempunyai kekuatan dalam melakukan tawar menawar.

Menurut Hartson S. (2010), mengatakan bahwa kuantitas penjualan merupakan pencapaian penjualan yang dinyatakkan dalam bentuk kuantitatif dari segi fisik atau 
volume dengan memperhatikan beberapa faktor seperti kondisi pasar, mengadakan pameran, serta memberikan potongan harga. Dalam kegiatan pemasaran kenaikan volume penjualan merupakan ukuran efisiensi, meskipun tidak setiap kenaikan volume penjualam diikuti dengan kenaikan laba. Dalam melakukan penjualan pengusaha slondok mampu memperhatikan bauran pemasaran seperti pengusaha slondok mampu melihat kondisi dan kemampuan penjual, pengusaha mampu melihat kondisi pasar serta mampu melakukan promosi dan pengusaha juga memberikan bonus sebagai pemberian yang mempengaruhi volume penjualan dengan harapan bahwa konsumen akan kembali untuk membeli produknya dengan menciptakan dan memperbaiki serta mempertahankan hubungan pertukaran. Pengusaha slondok mampu menciptakan strategi pemasaran yang mengacu pada volume penjualan.

Kalau yang tawar dalam global 1 bulannya secara pribadi 3 sampai 4 ton itu tawar berasa kalau udah matang itu dibagi dalam $90 \mathrm{gr}$ sampai $110 \mathrm{gr}$ trus ada yang $1000 \mathrm{gr}$. Untuk prodak kami yaitu slondok, kami jual kalau yang mentah itu harga Rp. 10.000-12.000/kg tapi kalau yang sudah matang itu bisa Rp. 15.000-30.000/kg dan kita kasih bonus misal beli 20 bonus satu, beli 40 bonus 2. Kami juga melakukan promosi lewat pameran, tapi kami dibawa binaan Dinas. (P3, 25-26)

Paparan pengusaha diatas menjadi tolok ukur bahwa dalam meningkatkan volume penjualan, pengusaha slondok mampu melihat kebutuhan permintaan pasar dengan memberikan pelayanan yang terbaik bagi konsumen serta melakukan penjualan dengan mengikuti pameran. Sehingga pengusaha slondok dalam melakukan penjualan dapat membentuk pasar dengan menjadi penentu harga atau price maker dan pengusaha berperan sebagai penentu pembelian. Sehingga hal ini menjadikan pengusaha memiliki kekuatan tawar menawar yang tinggi. Berikut pernyataan pengusaha :
Untuk slondok sendiri kita punya kelas sendiri-sendiri kok. Jadi ada yang pasar itu membutuhkan kelas bawah kencang sampai bagus itu ada sekmennya sendiri-sendiri jadi kita masih aman tinggal kita menyakinkan konsumen bahwa prodak saya layak dibeli atau lebih baik. (P3, 157-159)

Dalam mempertahankan usahanya, pengusaha slondok menerapkan strategi penjualan yang akhirnya mampu meningkatkan penjualan. Pengusaha menyadari bahwa ketika perusahaannya mampu menerapkan strategi penjualan maka secara otomatis akan membuat konsumen tetap loyal terhadap pembelian produknya. Adapun strategi yang diterapkan oleh pengusaha adalah melakukan inovasi produk, mengenali pasar, memilih lokasi pasar, meggunakan media sosial, menentukan target penjualan serta memperbaiki sistem pelayanan. Artinya produknya mau dijual kepada siapa, dan untuk pasar slondok pasarnya cukup besar dan produk slondok untuk semua kalangan (dikonsumsi oleh anak-anak sampai orang dewasa). Hal ini sesuai dengan pendapat Kotler (2011), strategi penjualan adalah proses perencanaan dan pelaksanaan, pemikiran, penempatan harga promosi serta penyaluran gagasan barang dan jasa untuk menciptakan pertukaran yang memenuhi sasaran-sasaran individu dan organisasi. Beikut paparan pengusaha.

Kami melakukan inovasi prodak yaitu dalam variasi rasa, ada rasa rendang, rasa balado dan tawar. Selain itu, pengirimannya dan atau cara penyampainnya yang kita inovasikan. Dalam melakukan service juga kami cepat karena slondok kami produksi terus sehingga ada yang minta kirim ya langsung kami kirim, seperti ke Sumatera, Jakarta dan lokasi Jawa. Waktu pengiriman juga tepat sehingga produsen tidak kecewa misalnya kalau kirim Sumatra, Jakarta ya kami paketkan lewat Pos (P3, 171-178)

Pengusaha dalam melakukan strategi 
penjualan mampu menarik pelanggan untuk tetap membeli produknya. Dengan cara membentuk loyalitas pelanggan, memberikan pelayanan yang maksimal, memberikan produk yang berkualitas, harga terjangkau, serta kemudahan pemesanan dan pengiriman. Sehingga pelanggan percaya kepada perusahaan dan akan tetap membeli produk slondok, dan dengan demikian pelanggan tidak akan beralih ke kompetitor baru perusahaan. Dalam hal ini, strategi penjualan yang dimiliki oleh pengusaha slondok mempunyai kekuatan tawar menawar.

Pengusaha dengan informasi yang lengkap terkait produk terutama harga, akan menjadikan pengusaha memiliki keuntungan serta kekuatan di dalam tawar menawar. Dalam hal ini, pengusaha slondok dalam melakukan usahanya dengan mudah memperoleh informasi harga dari pemasok. Hal ini sesuai dengan pendapat Porter (2010) dan Lampel (2011), informasi konsumen artinya dengan informasi yang lengkap pembeli dapat memperoleh harga yang paling menguntungkan dan dapat menyanggah penjual jika penjual mengatakan kelayakan hidup mereka terancam. Pemasok akan memberikan informasi ketika ada kenaikan harga bahan baku dari petani. Karena pengusaha melakukan transaksi secara langsung dan menanyakan harga bahan baku dan dengan mudah akan mendapatkan informasi. Hal ini juga terjadi karena antara pemasok dan pengusaha sudah lama menjalin hubungan kerja sama dan mereka tetap mempertahankan hubungan baik ini dengan saling percaya. Berikut paparan pengusaha:

Kami memperoleh informasi harga dari pedagang/pengepul singkong. Sehingga dari informasi harga itu kami bisa hitung-hitung untuk slondok berapa, gitu. Saat panen raya harga bahan baku sangat murah sekitar Rp. 200,- per $\mathrm{kg}$ (harga bisa ditawar). Namun, jika musim tanam bahan baku menjadi langka sehingga harga / $\mathrm{kg}$ bisa mencapai Rp. 2500,- per kg. Karena kami juga sudah lama kenal. (P3, 37-41)

Pengusaha slondok memanfaatkan informasi konsumen untuk meningkatkan kemajuan usahanya, artinya dengan mengetahui informasi harga dari pemasok pengusaha mampu melakukan analisis perhitungan yang mengacu pada harga produknya. Dalam meningkatkan kekuatan tawar menawar pengusaha juga dapat memberikan informasi yang jelas mengenai produk yang dimiliki dan sebaliknya pemasok juga memberikan informasi tentang harga bahan baku kepada pengusaha. Sehingga dari informasi konsumen, pengusaha dapat menentukan biaya pembelian. Pengusaha slondok cenderung mencari harga yang lebih menguntungkan sehingga akan menggunakan dananya untuk melakukan pembelian secara selektif guna memperoleh keuntungan yang maksimal. Hal ini sesuai dengan pendapat (Porter 2010 dan Lampel 2011), biaya pembelian artinya apabila produk yang dibeli dari industri merupakan bagian besar dari biaya atau pembelian yang dilakukan konsumen, konsumen cenderung untuk mencari harga yang menguntungkan dan menggunakan dananya untuk melakukan pembelian yang selektif. Pengusaha peka karena pengusaha mengetahui informasi harga dari pemasok sendiri tetapi pengusaha pun membeli bahan baku dengan melihat kualitas. Apabila kualitasnya bagus maka harganya juga mahal misalnya ketika kualitas yang diminta tersedia maka pengusaha akan berani untuk membayar mahal tetapi sebaliknya ketika kualitas yang diminta tidak tersedia maka pengusaha akan membeli dengan harga rendah. Selain kualitas, harga juga dipengaruhi oleh musim dan saingan dengan pabrik Tapioka. Ketika musim kemarau maka harga bahan baku tinggi bisa mencapai Rp. 2500,- per kg dan ketika musim panen raya maka harga bahan baku rendah bisa Rp. 200,- per kg.

Melihat paparan diatas dapat dikatakan bahwa dalam merencanakan pembelian, pengusaha memanfaatkan informasi konsumen dan informasi pemasok bahan baku untuk menganggarkan berapa biaya yang harus dikeluarkan untuk membeli bahan baku, membayar tenaga kerja serta berapa 
keuntungan yang akan diperolehnya. Dalam usaha slondok semua jenis singkong dengan semua ukuran dimanfaatkan sehingga tidak ada yang terbuang. Sehingga dalam hal ini, informasi konsumen dan informasi pemasok bahan baku, biaya yang dimiliki oleh pengusaha slondok mempunyai kekuatan tawar menawar.

Dalam memenuhi kebutuhan bahan baku, tentunya perusahaan memiliki pemasok. Dalam hal ini pemasok dalam industri slondok tidak didominasi oleh satu pemasok, perusahaan slondok memiliki pemasok 2-4 pemasok, hal ini dikarenakan apabila satu supplier bermasalah maka perusahaan dapat memakai supplier lain dan proses produksi dapat tetap berjalan dengan lancar. Hal ini sesuai dengan pernyataan pengusaha:

Kami pesan bahan baku itu dari beberapa tempat seperti dari Boyolali, Temanggung, Gunung Kidul, dan Wonosobo (Solo Raya). Kalau dari satu pemasok saja ya jelas tidak bisa. (P3, 19-20)

Dalam usaha slondok pengusaha menyadari bahwa usahanya akan terus berkembang ketika pasokan bahan baku tetap terpenuhi (kontinyu). Sehingga pengusaha dalam menjalankan usahanya memiliki lebih dari satu pemasok. Hal ini sesuai dengan pendapat Porter (2010) dan Lampel (2011), deferensiasi produk artinya apabila produk yang dibeli industri adalah produk standar atau tidak terdeferensiasi, pengusaha yakin bahwa mereka akan selalu dapat menemukan pemasok alternatif serta dapat membandingkan pemasok yang satu dengan pemasok yang lain. Dalam mengatasi persaingan yang semakin ketat diantara pesaing, strategi yang dapat dilakukan pengusaha adalah dengan memperluas permintaan atau memperkuat tingkat diferensiasi produk dalam meningkatkan kualitas produk. Kemudian pengusaha juga dapat melakukan pemasaran yang baik, dan menerima saran dari konsumen tanpa mengubah standar kualitas yang ada. Berikut paparan pengusaha:

Kita intropeksi ke dalam perpindahan itu apa kalau mencari kualitas yang lebih tinggi ya enggak apa-apa kita harus perbaiki dan kita tetap mempertahankan kualitas. (P3, 145-147)

Bahan baku utama sendiri, sebagian besar perusahaan tidak memiliki diferensiasi, sehingga persaingan pada bahan baku yang ada cenderung rendah. Melihat hal tersebut diatas deferensiasi produk yang dilakukan oleh pengusaha dapat menentukan kekuatan tawar menawar.

Selain deferensiasi produk, pengusaha menyadari bahwa identitas merek sangat penting dan sangat besar pengaruhnya dalam menarik minat konsumen Dengan demikian konsumen akan lebih memilih membeli produk slondok dengan pertimbanganpertimbangan tersebut. Contoh pengusaha dalam memberikan pelayanan yang baik dan memuaskan adalah mengirim tepat waktu (ke Jakarta, dan luar Pulau Jawa) memberikan harga terjangkau, kualitas terjamin. Hal ini akan menjadi pertimbanngan khusus di dalam keputusan konsumen ketika beralih ke pengusaha lain karena dihadapkan pada biaya yang besar. Oleh karena itu, deferensiasi produk dan identitas merek yang dimiliki oleh pengusaha slondok mempunyai kekuatan tawar menawar. Berikut paparan pengusaha:

Merek slondok kami adalah Telomoyo, karena kami dekat dengan gunung Telomoyo hehehe dan kami rasa nama itu mewakili Jawa Tengah serta kalau berbicara merek itu taruhannya nama baik. (P3, 80-82).

Pengusaha slondok menyadari bahwa untuk menarik konsumen atau pelanggan membeli produknya, pengusaha melakukan penawaran yang berbeda dengan memberikan nilai tambah atau lebih kepada konsumen sehingga mampu menarik konsumen yaitu dengan memberikan merek bagi produknya, yang mana merek tersebut lebih terkesan dekat dengan konsumen. Identitas merek sangat mempengaruhi kelayakan suatu produk, yang akan mengarah pada intensi pembelian yang positif. Pengusaha menyadari bahwa merek sangat penting karena bagi pengusaha merek adalah taruhan nama baik 
serta merek merupakan penanda identitas dari sebuah produk. Hal ini sesuai dengan pendapat Kotler, dalam Kismono (2011), identitas merek adalah suatu simbol yang digunakan untuk memberikan identitas pada produk atau untuk membedakannya dengan produk lain. Sehingga sangat penting bagi pengusaha untuk memiliki hak merek untuk memotivasi dan mendorong pengusaha lain agar dalam melakukan usaha bisa kreatif sebagai nilai tambah dalam usahanya. Dalam hal tersebut diatas dapat dikatakan bahwa identitas merek yang dimiliki oleh pengusaha dapat menentukan kekuatan tawar menawar.

Selain identitas merek, pengusaha juga memiliki HAKI (Hak Atas Kekayaan Intelektual) untuk bisa mengendalikan produk yang beredar. Berikut pernyatan pengusaha:

Disanakan ada itu ada kendali perlindungan konsumen haki halal dan plit saya dan ada juga ikatan dari saya seperti Orang-orang grosir atau konsumen langganan saya. (P3, 94-96).

Banyak maanfat dari memiliki hak atas kekayaan intelektual, salah satunya adalah bisa memiliki hak paten, merek dan hak cipta. Selain itu, pengusaha juga memiliki sales untuk menawarkan dan memberikan informasi mengenai produk yang dimiliki perusahaan kepada pelanggan, dan pelanggan dapat bertanya langsung mengenai informasi yang dibutuhkan sehingga pelanggan mendapatkan informasi yang jelas mengenai produknya. Oleh sebab itu, HAKI dan sales yang dimiliki pengusaha dapat menentukan kekuatan tawar menawar.

Pengusaha slondok menyadari bahwa tanpa melakukan promosi produknya tidak akan mencapai target penjualan dan akhirnya akan mengalami kerugian. Sehingga dalam melakukan pemasaran produknya pengusaha merangsang dan menyebarkan informasi tentang ketersediaan dan kondisi produk kepada konsumen. Hal ini sesuai dengan pendapat (Porter 2010 dan Lampel 2011), promosi artinya suatu usaha dari pemasar dalam menginformasikan dan mempengaruhi orang atau pihak lain sehingga tertarik untuk melakukan transaksi atau pertukaran produk barang atau jasa yang dipasarkannya. Tahun 90-an pengusaha melakukan promosi lewat telegram dan telepon. Menurut pengusaha slondok untuk memperkenalkan produknya ada harga yang harus dibayar yaitu tenaga dan waktu. Seiring berjalannya waktu dan perkembangan teknologi, pengusaha melakukan promosi dengan memanfaatkan media sosial, plang, pameran dan brosur dengan tujuan menarik minat konsumen terhadap hasil produksinya. Berikut paparan pengusaha:

Kami juga melakukan promosi lewat pameran, dan secara online juga. Sekarang banyak kemudahan dalam melakukan promosi. Spanduk juga ada, itu di jalan Semarang- Yogja. Dulu ya lewat telp tahun 90-an dan telegram juga. Wah itu saya senang sekali saya paketin trus kirim. Kadang saya harus antri di wartel dari jam 7 malam-jam 9 malam baru dapat giliran telp. (P3, 114125).

Pengusaha mampu menginformasikan dan mempengaruhi orang atau pihak lain untuk memperkenalkan produknya sehingga konsumen tertarik untuk melakukan transaksi atau pertukaran produk barang yang dipasarkannya. Dalam hal ini, promosi yang dilakukan oleh pengusaha slondok dapat menciptakan pasar yang luas.

Dalam mengembangkan usahanya pengusaha mampu melihat pangsa pasar untuk slondok. Pengusaha melihat pasar dan menyediakan produk yang berkualitas. Hal ini sesuai dengan hasil analisis (Kotler, 2011), syarat adanya pasar adalah harus terdapat orang-orang dengan kebutuhan dan keinginan tertentu dan satu atau lebih produk yang dapat memuaskan kebutuhan ini. Selain itu, para pembeli juga mau dan mampu membeli produk yang memuaskan kebutuhan keinginan mereka, dengan demikian pengusaha mampu menguasai pasar serta pengusaha mampu memanfaatkan pesaingpesaing yang ada guna keberhasilan usahanya, dengan cara mempertahankan pelanggan sebanyak mungkin, baik pelanggan baru maupun pelanggan lama. Dengan 
melakukan inovasi produk. Untuk usaha slondok di Desa Sumurarum terdapat kurang lebih 200 pengrajin slondok, artinya usaha slondok mempunyai persaingan yang besar. Dalam menghadapi besarya persaingan pengusaha mampu mengidentifikasikan pesaing dengan melakukan strategi bertahan. Selain pesaing yang terdapat dalam perusahaan, pengusaha juga bersaing dengan pabrik Tapioka.

Kalau persentasi tepat di slondoknya kita aman karena pertama kita punya pasar trus persaingan itu juga tidak hanya slondok tapi dengan produkproduk lain. Sekarangg itu persaingannya luar biasa, tapi kita bersaingnya dengan macam-macam prodak. Pesaing secara internal yaitu untuk slondok sendiri itu juga ada 200 pengrajin yang terlibat, sementara untuk prodak olahan lainnya juga tambah banyak gitu. (P3, 170-173).

Dalam menguasai dan menghadapi persaingan yang ada, pengusaha mempunyai cara tersendiri yaitu dengan melakukan inovasi produk, menjaga dan mempertahankan kualitas, produksi berbagai macam makanan ringan berbahan baku utama singkong, melakukan promosi serta pengusaha juga mempunyai cara tersendiri dalam menghadapi persaingan dengan pabrik Tapioka yaitu pengusaha memanfaatkan jenis singkong pahit. Khusus untuk jenis singkong pahit, langkah pertama yang dilakukan oleh pengusaha ialah mencuci bersih dan menjemur dibawa panas matahari selama 3 hari dengan tujuan agar tidak keracunan. Berikut paparan pengusaha :

Selain itu ada dengan pabrik Tapioka, kalau pas buka mereka ambil/beli singkong itu tidak pandang bulu artinya baik kecil, besar mereka tidak pilih-pilih. Kami punya strategi yaitu pake jenis singkong yang pahit tapi harus dijemur di bawa sinar matahari selama 3 hari supaya tidak keracunan (P3, 173-178).

Dapat disimpulkan bahwa persaingan perusahaan slondok di Desa Sumurarum cenderung tinggi. Hal ini diketahui dari jumlah pesaing yang ada di Desa Sumurarum saat ini mencapai 200 perusahaan yang bergerak di bidang yang sama yaitu industri slondok. Peningkatan jumlah industri slondok ini juga dibuktikan dari peningkatan pesaing yang memproduksi sejenis sekitar 4 sampai 5 perusahaan setiap tahunnya. Peningkatan jumlah industri slondok tersebut mengakibatkan persaingan yang semakin kompetitif dengan ditandai permintaan pasar yang juga meningkat.

Persaingan yang semakin tinggi juga dapat dilihat dari semakin banyaknya perusahaan yang memiliki diferensiasi produk dari pesaing lainnya. Dalam hal ini, Perusahaan slondok memiliki diferensiasi produk pada produk campuran yang dapat menekan biaya produksi namun tetap memperhatikan kualitas yang ada, sehingga perusahaannya dapat memberikan manfaat kepada konsumen dengan memberikan harga yang sesuai dan namun produk berkualitas. Sehingga dalam hal ini, pengusaha mampu menguasai pasar dan mampu untuk bersaing, artinya pengusaha mempunyai kekuatan tawar menawar. Pertumbuhan pangsa pasar pembeli juga dapat meningkatkan kekuatan tawar menawar pembeli, dimana pertumbuhan pangsa pasar sejauh ini mencapai $5-10 \%$ tiap periode, hanya saja pangsa pasar pembeli tidak konstan dan tergantung dari daya beli masyarakat.

Pengusaha menyadari bahwa dari semua variabel penentu kekuatan tawar menawar, variabel teknologi merupakan alat ukur kekuatan tawar menawar yang ampuh karena teknologi dapat membantu memperbesar dan membangun suatu usaha serta mempunyai nilai tambah. Hal ini sesuai dengan pendapat (Miarso, 2011), teknologi merupakan suatu bentuk proses yang meningkatkan nilai tambah atau teknologi merupakan suatu bagian dari sebuah integral yang terdapat di dalam suatu sistem tertentu. Artinya proses yang berjalan tersebut dapat menggunakan atau menghasilkan produk tertentu, dimana produk yang dihasilkan tidak terpisah dari produk lain yang telah ada. Berikut penyataan pengusaha: 
Hal yang paling penting adalah berpindah ke teknologi seperti kami menggunakan oven dan untuk packingnya kami ganti dengan vacuum sealer. Sehingga kontinuetas produk tetap; Inovasi produk; Kualitas kami jaga; (P3, 207-208)

Dengan pemanfaatan teknologi pengusaha mampu bersaing dengan pesaingpesaing lain serta mampu memenuhi permintaan pasar. Awalnya pengusaha hanya pemanfaatkan sinar matahari untuk pengeringan bahan baku serta alat-alat tradisonal, tetapi karena semakin pesatnya persaingan dan semakin cangkihnya teknologi, pengusaha beralih dari penggunaan tradisonal ke teknologi. Dari pernyataan diatas dapat disimpulkan bahwa teknologi yang digunakan oleh pengusaha memiliki kekuatan tawar menawar.

Menurut DR Payaman S, 2009, tenaga kerja adalah penduduk yang sudah atau sedang bekerja yang menghasilkan barang atau jasa. Sedangkan Tenaga kerja terampil adalah tenaga kerja yang memiliki keahlian dalam bidang tertentu dengan melalui pengalaman kerja. Dalam perusahaan slondok, salah satu variabel yang mempengaruhi kekuatan tawar menawar pengusaha adalah tenaga kerja terampil. Berikut pernyataan pengusaha :

Orang-orang yang kerja disini ya sudah berpengalaman semua karena ah itu kami sudah buat slondok sejak kecil. Semua disini mempunyai keterampilan yang bagus dan kami juga mengutamakan budaya kerja jadi kami tidak ngawur kerjanya. (P3, 211-214)

Dalam meningkatkan kekuatan tawar menawar pengusaha perlu memperhatikan tenaga kerja. Tenaga kerja terampil akan memproduksi produk-produk yang berkualitas karena mereka adalah orang-orang yang mempunyai keterampilan dari pengalaman kerja mereka selama bertahuntahun.

Strategi Alternatif Yang Diterapkan Oleh
Pengusaha Slondok Di Desa Sumurarum
Kecamatan Grabag Dalam Meningkatkan Kekuatan Tawar Menawar

Setelah melihat kondisi dari hasil penelitian pengusaha slondok maka selanjutnya akan dianalisis strategi altrenatif yang dimiliki pengusaha slondok selain strategi generik menurut Porter, sebagai berikut :

a. Kuantitas pembelian, pengusaha slondok menyadari bahwa dengan melakukan pembelian bahan baku dalam jumlah yang besar merupakan kekuatan pengusaha dalam melakukan tawar menawar.

b. Teknologi merupakan hal penting dalam meningkatkan kekuatan tawar menawar bagi pengusaha. Pengusaha slondok menyadari bahwa dengan memanfaatkan teknologi akan memberikan nilai tambah dalam usaha slondok.

c. Relasi, dalam melakukan suatu usaha relasi sangat berperan penting karena dengan adanya relasi maka pengusaha mempunyai peluang yang besar dalam mempengaruhi kekuatan tawar menawar. Pengusaha slondok sangat memperhatikan dan menjaga hubungan baik dengan pemasok dan pembeli.

d. Tenaga kerja, usaha slondok tidak akan berkembang tanpa tenaga kerja yang terampil, tenaga kerja yang berpengalaman.

e. Informasi harga, untuk meningkatkan kekuatan tawar menawar pengusaha slondok memanfaatkan informasi harga sebagai strategi alternatif. Pengusaha menyadari bahwa dengan adanya informasi yang cukup, pengusaha mampu bersaing.

\section{PENUTUP}

\section{Kesimpulan}

Dari hasil penelitian dan pembahasan dapat ditarik suatu kesimpulan bahwa:

1. Kekuatan tawar menawar pengusaha slondok dipengaruhi oleh beberapa variabel yaitu:

a. Kuantitas pembelian bahan baku 
yang diterapkan oleh pengusaha slondok dapat mempengaruhi harga, menentukan kualitas serta menentukan kuantitas sehingga hal tersebut merupakan kekuatan bagi pengusaha dalam melakukan tawar menawar.

b. Kuantitas penjualan yang dilakukan oleh pengusaha mampu menguasai pasar dengan menerapkan strategi penjualan. Sehingga pengusaha mempunyai kekuatan yang berpengaruh pada modal serta berdampak pada ukuran pasar.

c. Strategi penjualan yang diterapkan oleh pengusaha berupa inovasi produk dengan bermacam variasi rasa (3 rasa yaitu rasa rendang, balado dan tawar) sehingga strategi penjualan ini mempunyai pengaruh yang berdampak pada luasnya pasar (ukuran pasar) bagi pengusaha slondok.

d. Informasi harga yang diperoleh pengusaha mempunyai pengaruh dalam melakukan kekuatan tawar menawar karena dari informasi harga tersebut pengusaha mampu mengganggarkan biaya pembelian yang berdampak pada ukuran pasar.

e. Promosi dalam memperkenalkan produk slondok kepada masyarakat luas pengusaha menerapkan startegi yang mempengaruhi keberlangsungan perusahaan. Promosi yang dilakukan oleh pengusaha adalah dengan mengikuti pameran, brosur dan spanduk, selain itu pengusaha juga menjual secara online. Sehingga pengusaha mempunyai kekuatan dalam tawar menawar.

f. Pangsa pasar slondok cukup besar sehingga menekan pengusaha untuk melakukan strategi atau perbaikanperbaikan yang berdampak pada keuntungan perusahaan.

g. Pengusaha slondok melakukan pembaharuan teknologi dengan tujuan produk yang diproduksi lebih terjaga kualitasnya sehingga berdampak pada Gizi karena produk lebih terjaga kebersihannya serta tahan lama. Dalam hal ini, pengusaha menyadari bahwa dengan startegi pembaharuan teknologi, pengusaha mempunyai kekuatan dalam melakukan tawar menawar.

Selain itu kekuatan pengusaha slondok dalam melakukan tawar menawar juga dibentuk oleh pengusaha itu sendiri sebagai penentu harga atau price maker.

2. Strategi alternatif yang diterapkan oleh pengusaha slondok yaitu kuantitas pembelian, kuantitas penjualan, informasi harga, teknologi, service, relasi.

\section{Saran}

Penelitian lebih lanjut perlu melakukan "Bagaimana menyatukan UKM dalam meningkatkan Bargaining Power".

\section{DAFTAR PUSTAKA}

Bugin, Burham H.M, 2011. Penelitian Kualitatif: Komunikasi, Ekonomi, Kebijakan Publik, dan Ilmu Sosial. Jakarta: Kencana Premana Media Group.

Hunger, D., dan T. Wheelen. 2010. Strategic Management and Business Policy. New Jersey: Pearson Prentice

S, Hartono, 2009. Kuantitas Penjualan. Jakarta.

Kotler, P. 2011. Manajemen Pemasaran (Terjemahan). PT. Prenhallindo, Jakarta.

Lawrence R. Jauchdan William F. Gulueck, Manajemen Strategi dan Kebijakan perusahaan, Di Indonesiakan oleh Murad dan AR. Hary Sitanggang, Edisi ketiga, 2010.

Porter dalam Agus M, 2011, January. Strategi Bersaing. Jakarta

Sangadji, Sopiah, Sugiyono. 2012. Memahami Penelitian Kualitatif. Bandung: Alfabeta. 
Sugiyono. 2013. Metode Penelitian Bisnis

Kuantitatif, Kualitatif dan $R \& D$.

Bandung : Alfabeta

Supomo. 2011. Metodologi Penelitian Bisnis:

Untuk Akuntansi \& Manajemen. Yogyakarta : BPFE Anggota IKAPI.

Simanjuntak Payaman. 2009. Undang-undang tentang ketenagakerjaan. 